\title{
Ethnobotanical and economic value of Ravenala madagascariensis Sonn. in Eastern Madagascar
}

\author{
Nivo Rakotoarivelo ${ }^{1,2^{*}}$, Aina Razanatsima ${ }^{1}$, Fortunat Rakotoarivony ${ }^{1}$, Lucien Rasoaviety ${ }^{1}$, \\ Aro Vonjy Ramarosandratana², Vololoniaina Jeannoda², Alyse R Kuhlman ${ }^{3}$, Armand Randrianasolo ${ }^{3}$ \\ and Rainer W Bussmann ${ }^{3}$
}

\begin{abstract}
Background: Known worldwide as the "traveler's tree", the Malagasy endemic species Ravenala madagascariensis Sonn. (Strelitziaceae) is considered as an iconic symbol of Madagascar. It is a widespread species in the eastern part of the country with four different varieties which are well represented in Ambalabe community. All of them are used for different purposes and the species represents an important cultural value in the lives of the local population. However, uses of Ravenala are only generally well known by local population. Thus, in this study, we report on the different uses of Ravenala and its importance to the Ambalabe local people.

Methods: Semi-structured interviews among 116 people, 59 men and 57 women with ages ranging from 17 to 84 years old, free listing and market surveys were conducted in order to collect the vernacular names, the uses of Ravenala madagascariensis and the price of plant parts sold in local market. Then, the uses were categorized according to Cámara-Leret et al. classification.

Results: Different parts of the plant are currently used by local population, which are grouped as heart, trunk, leaves, petioles and rachis. Seven categories of use were recorded, most cited include: human food, utensils and tools, and house building. The most commonly used parts are trunk, heart, leaves and petioles for which the price varies between \$3-15. Uses mentioned for construction (floor, roofs and wall), human food and utensils and tools are the most frequent and salient for local population. But the use of the plant as first materials for house building is revealed to be the most important for them.

Conclusions: Ravenala madagascariensis is very important to the Ambalabe communities because for local population, it represents the Betsimisaraka cultural and traditional use of the plant for house building. Moreover, none of its parts are discarded. The harvest and sale of $R$. madagascariensis for building materials can also provide an additional source of income to the family. Besides, using Ravenala in house construction reduces the use of slow growing trees and contributes to the sustainable use of natural forest resources.
\end{abstract}

Keywords: Ravenala madagascariensis, Ambalabe, Madagascar, Ethnobotany, Uses, Conservation

\section{Background}

Madagascar has a remarkable wealth in terms of vegetation and endemic species. The island is composed of a multitude of natural environments [1] which harbor a unique and globally important assemblage of plant species [2]. In the eastern part of Madagascar, Ravenala

\footnotetext{
* Correspondence: nivo.rakotoarivelo@mobot-mg.org

'Missouri Botanical Garden, Madagascar Research and Conservation Program, BP 3391, Antananarivo 101, Madagascar

${ }^{2}$ Department of Plant Biology and Ecology, University of Antananarivo, BP 906, Antananarivo 101, Madagascar

Full list of author information is available at the end of the article
}

madagascariensis (Figure 1), an endemic species also known as the traveler's palm or traveler's tree, is considered as an iconic symbol of the island. While Ravenala madagascariensis occurs in both primary rainforest and open secondary growth [3], it is known to form a very characteristic vegetation called "Ravenala forest" [4], due to the high abundance of the species (Figure 2).

Always regarded as monospecific, Ravenala madagascariensis has recently proved to be a complex aggregate of at least four recognized varieties, which might deserve the rank of species [5]. Each variety can be distinguished 


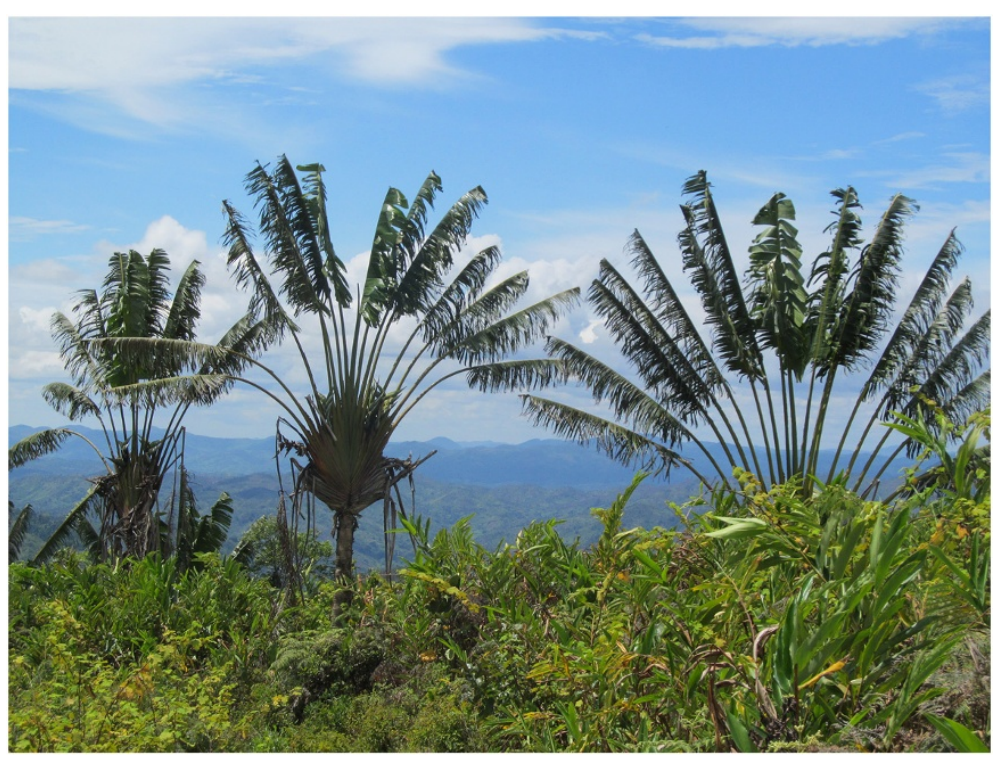

Figure 1 Pictures of Ravenala tree.

according to macromorphological characters, growth habits and habitat preferences [6,7]. Four varieties of Ravenala are well represented in Ambalabe community in Eastern Madagascar. Three of them match the three recognized vernacular names cited by Blanc et al. in 2003, such as Hirana (known before as menahirana, from which mena means red and hirana means fringes because it can be easily recognized by the sheath which is borded by red fringes), Bemavo (be means many and mavo means gray in Betsimisaraka language because of the gray powder along the sheath) and Horonorona (the name comes from its cespitose habit which is in tuft). The variety Hirana occurs both inside and outside Vohibe forest which belongs to Ambalabe commune, and the two varieties Bemavo and Horonorona are only encountered outside the forest. The fourth one which only occurs inside Vohibe forest has a red sheath and is locally called Menafalaka (mena means red and falaka means sheath in Malagasy) (Figure 3).

Ravenala madagascariensis is well known as an ornamental plant and is cultivated in many tropical regions. Aside from ornamental value, Ravenala appears to have many uses $[4,8,9]$. In the Ambalabe community, the four varieties are all used by local population. Our purpose was to report on

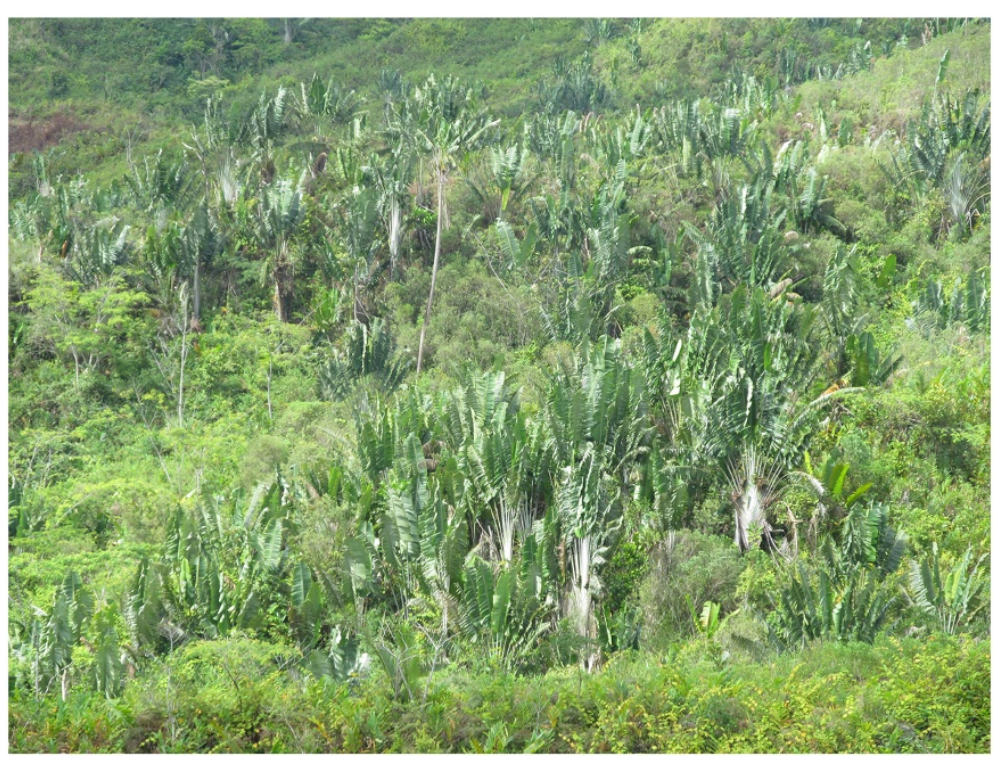

Figure 2 Population of Ravenala madagascariensis called « Ravenala forest ». 


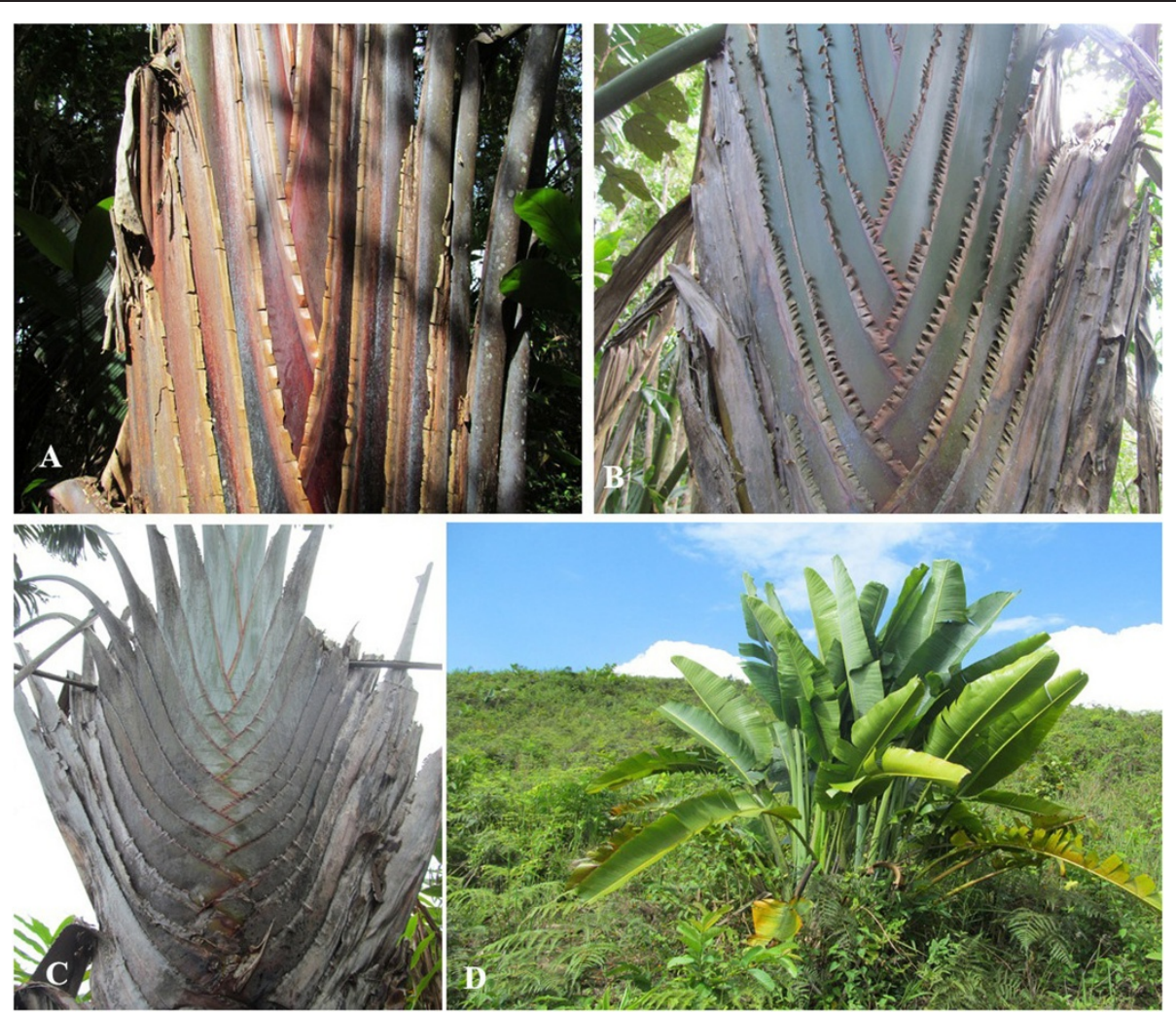

Figure 3 Pictures of the four varieties of Ravenala found in Ambalabe. (A) Menafalaka: found only in the forest, the picture shows its red sheath. (B) Hirana: occurs within and outside the forest, picture showing the sheath borded by fringes. (C) Bemavo: grows on deforested slopes, with the petioles covered with gray powders. (D) Horonorona: picture showing its cespitose habit.

the different uses of Ravenala and to assess its ethnobotanical and economic value for the local population.

\section{Methods}

This study is conducted within a framework of an existing collaboration between the local population and the staff at the Missouri Botanical Garden Ambalabe Conservation Project. Fieldwork was conducted from October-December 2013 in order to collect vernacular names, the plant use and the local price of the used plant parts. A community meeting was held to explain the objective of the study in order to obtain a prior consent from the administrative authorities, traditional leaders and the local population. The surveys were done in the presence of a local guide and were conducted in the local dialect of Malagasy.

\section{Study Site}

This study was conducted in the rural commune of Ambalabe, $72 \mathrm{~km}$ northwest of the district of Vatomandry, which is one of the 7 districts of the Atsinanana Region in Eastern Madagascar and the nearest large city and marketplace (Figure 4). Ambalabe is a very remote area, and is only accessible by road via the Provincial Interest Road (RIP) $\mathrm{N}^{\circ}$ 8, linking it to Vatomandry via
Antanambao Mahatsara. The road is only passable in the dry season from August to Obtober by $4 \times 4$ vehicles up to Ambodinonoka (46 km from Vatomandry). Local people, for cost and accessibility reasons, prefer walking or using wooden canoes via Sakanila River from the village of Befatakana to Tsarasambo, or sometimes use motorcycles from the village of Vohidiavolana to Vatomandry. The whole commune covers 17,437 ha including the forest area, with a population of 10,961 inhabitants in 2013, of which $95 \%$ are farmers. About 42 villages and 1,437 households are recorded within the commune (rural commune of Ambalabe, personal communications).

The rural commune of Ambalabe is characterized by rough topography, with valley systems with steep slopes of $10-60 \%$, and narrow, almost reduced bottomlands. This topographical system of alternating mountain and valley typically represents the landscape in this part of Madagascar. The community is subject to a humid tropical climate [10] with an average annual rainfall of $1773 \mathrm{~mm}$, distributed over 214 days. The average annual temperature is $24^{\circ} \mathrm{C}\left(75^{\circ} \mathrm{F}\right)$.

\section{Ethnobotanical surveys}

Due to deficiencies in roads and to the rough topography, local populations rely on the use of plants in their 


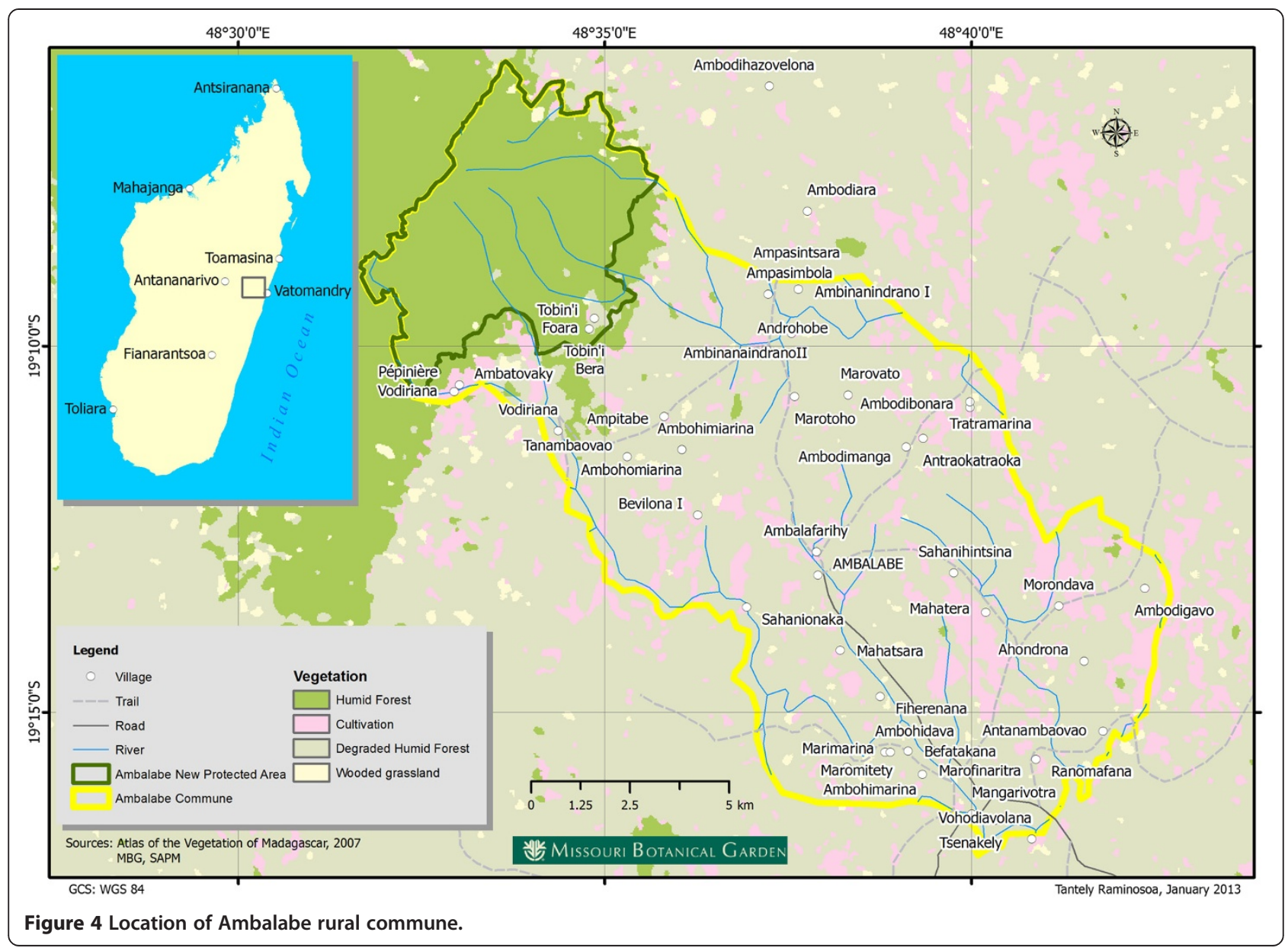

daily life. Ravenala madagascariensis is one of the most important plant resources used by local communities in Ambalabe. In order to know the different uses of Ravenala and to assess its importance, semi-structured interviews and market surveys were carried out within villages after obtaining prior informed consent [11-14] from local and tribal leaders and survey participants. Questionnaires about Ravenala were established and used as a guide for the surveys and informants were asked to cite uses they know (free list) for Ravenala and the price of materials they use (Additional file 1). Interviews were conducted in Malagasy local dialect by the four first authors, who are native speakers. A local guide acted as a dialect translator as necessary. Field walks with some participants were also done in order to identify the four varieties of Ravenala and pictures were taken. Then, uses were categorized according to Cámara-Leret et al. [15] use category.

\section{Analysis}

Data analysis was performed using the ANTHROPAC ${ }^{\circ}$ 4.0 software package $[16,17]$ and XLSTAT ${ }^{\oplus}$-Pro 7.5 . In this study, ANTHROPAC ${ }^{\circ}$ was used for the analysis of free listing data. The results were expressed as frequency (\%) and salience (a value that lies between 0 and 1). Frequency is the repetition of mentions during the surveys, of which one specific use of one plant part by one informant is counted as one mention. Salience is a statistic accounting for rank and frequency of the uses (e.g., one use is more salient when it appears more often and earlier in freelists) [18]. Thus, uses that are frequently mentioned are assumed to be highly salient to respondents, and uses recalled first are assumed to be more salient than uses recalled last [19]. Most frequent and most salient use of Ravenala is then considered as the important use of the species for the local population.

$\mathrm{XLSTAT}^{\oplus}$-Pro 7.5 was used for the analysis of variance or ANOVA in order to see the difference between men and women knowledge on the uses of Ravenala.

\section{Results and discussion}

Ethnobotanical Knowledge

Thirteen villages were visited during the ethnobotanical surveys and 116 people were interviewed, of which 59 
(51\%) were men, and 57 (49\%) women. The age of informants ranges from 17 to 84 years old. Ravenala madagascariensis is generally known locally as Fontsy, but there are four varieties encountered in Ambalabe known as Menafalaka, Hirana, Bemavo and Horonorona. Three of them, such as Hirana, Bemavo and Horonorona are already recognized by Blanc et al. [5].

In general, uses mentioned by participants during the free listing exercise correspond to the local name Fontsy. The species is used as human food, animal food, medicine, house building, tools and utensils, for environmental purposes, and also for other uses (Table 1). The frequency and the salience of each use cited were given with the table. However, some specific uses were attributed by participants to each variety depending on the used plant parts (Table 2). The plant is also known to provide seed arils and nectars which are eaten by lemurs and birds [3], and its leaves have an antidiabetic activity [20].
Twenty-six types of use of Ravenala were recorded. Women knew more uses (22 cited) than men (18 cited), however the analysis of variance shows that no significant difference were shown from the two genders (Figure 5), with $\mathrm{P}=0.6>0.05$. For both, the most frequent and salient uses cited are: floor, food, roofs, wall and rope.

All parts of the Ravenala tree are used by local people. The heart of Ravenala, locally called Ovitra of the two varieties Bemavo and Hirana, is edible and can be eaten by people or livestock. The variety Bemavo is widely preferred because it is sweeter. The variety Hirana is slightly bitter but people occasionally eat it [8]. Ravenala is used for food especially during "starvation period", and the heart of the plant is often used as fodder during this period as well.

In terms of construction, flattened pieces of the trunk of all varieties are used for floor, but Bemavo is the most used because it has the biggest trunk. To make roofs, leaves of three varieties can be used, but Horonorona is

Table 1 Different uses of Ravenala madagascariensis recorded among the local people in Ambalabe with their frequency

\begin{tabular}{|c|c|c|c|c|}
\hline Use category & Uses & Parts used & Frequency (\%) & Salience \\
\hline Human food & Cooked as vegetable & Heart & 57.8 & 0.394 \\
\hline Animal food & Fodder for domestic animals (zebu) & Heart & 1.7 & 0.003 \\
\hline \multirow[t]{7}{*}{ Construction } & Floor & Trunk & 64.7 & 0.461 \\
\hline & Roofs & Leaves & 50 & 0.404 \\
\hline & Wall & Petioles and trunk & 42.2 & 0.303 \\
\hline & Beehives & Trunk & 3.4 & 0.024 \\
\hline & Chicken coops & Leaves & 1.7 & 0.012 \\
\hline & Gable & Trunk & 0.9 & 0.009 \\
\hline & Doors & Petioles & 0.9 & 0.003 \\
\hline Environmental uses & Cultivated in the garden as ornamental plant & Whole plant & 0.9 & 0.002 \\
\hline \multirow[t]{3}{*}{ Medicinal and veterinary } & Dizziness & Young leaves & 1.7 & 0.011 \\
\hline & Stomach-ache & Young leaves & 1.7 & 0.006 \\
\hline & Regulates albumin levels & Heart & 0.9 & 0.003 \\
\hline \multirow[t]{12}{*}{ Utensils and tools } & Ropes and moorings & Petiole fibers & 25.9 & 0.112 \\
\hline & Winnowing trays & Petioles & 15.5 & 0.066 \\
\hline & Spoons & Leaves & 9.5 & 0.016 \\
\hline & Baskets & Petioles & 3.4 & 0.03 \\
\hline & Fishing nets & Leaf rachis & 3.4 & 0.027 \\
\hline & Mats & Petioles & 2.6 & 0.017 \\
\hline & Cupboard & Trunk & 0.9 & 0.006 \\
\hline & Chicken baskets & Petioles & 0.9 & 0.005 \\
\hline & Beds & Trunk & 0.9 & 0.004 \\
\hline & Mat for food and market display & Fresh, whole leaf & 0.9 & 0.004 \\
\hline & Dishes & Leaves & 0.9 & 0.004 \\
\hline & Tables & Trunk & 0.9 & 0.002 \\
\hline Other uses & Hosts edible larvae & Trunk & 0.9 & 0.006 \\
\hline
\end{tabular}


Table 2 Specific uses of the four varieties of Ravenala madagascariensis according to surveys done in Ambalabe

\begin{tabular}{llll}
\hline Local name & Use category & Uses & Parts used \\
\hline Bemavo & Human food & Cooked as vegetable & Heart \\
& Construction & Wall & Petioles and trunk \\
& & Floor & Trunk \\
& Utensils and tools & Roofs & Leaves \\
Hirana & Ropes and moorings & Petiole fibers \\
& Construction & Cooked as vegetable & Heart \\
Horonorona & Medicinal and veterinary & Floor & Trunk \\
Menafalaka & Regulates albumin levels & Heart \\
& & Floor & Trunk \\
& Construction & Roofs & Leaves \\
\hline
\end{tabular}

widely preferred due to its longevity. However, using the species for rope is much more frequent because it is used whenever local people tie something, even for housing.

The analysis of the use of Ravenala (Table 1) shows that the species is mostly mentioned for house building and food. As assumed by Collins et al. [21], we considered that uses which received the highest number of mentions are the most prevalent in the communities and also of the greatest importance to people living in the villages. This means that Ravenala is primarily used as first materials for construction in Ambalabe commune, in addition to other construction materials like wood for posts or rafters. Indeed, it is almost the common use of the plant in the East Coast of Madagascar and villagers depend on Ravenala for shelter [22]. In Ambalabe community, the species is used for traditional housing which is encountered in most villages, and also for temporary houses in the field in which leaves are also used for walls (Figure 6). The heart of the species is also

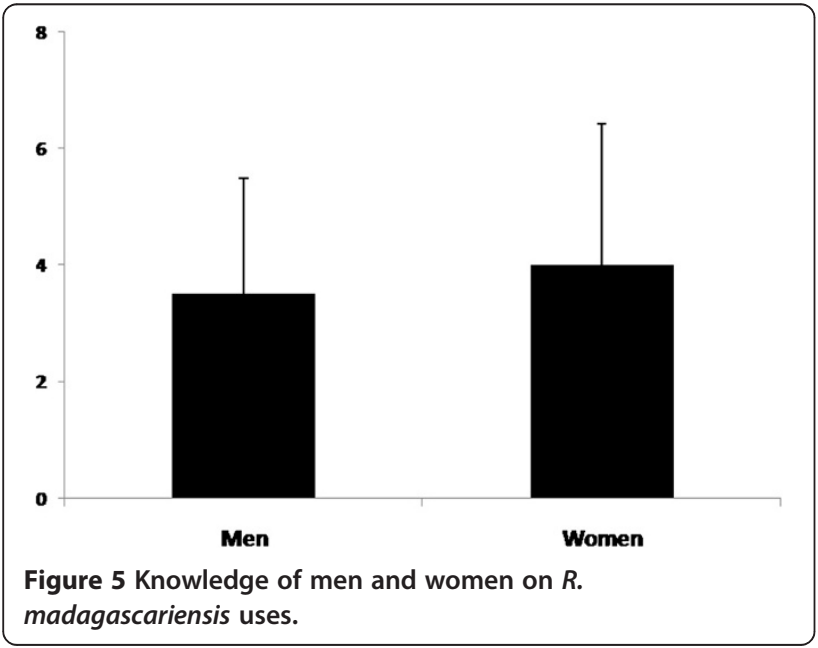

used as substitute for food. It is a food rich in minerals [8]. Frequency for each use of Ravenala was considered in this study. The salience takes in account simultaneously the number and the order of citation.This analysis highlights the important use of Ravenala in house construction (floor, roofs, wall), and for food.

\section{Economic Value}

As far as the economic value of Ravenala is concerned, we only considered the two varieties, Bemavo and Horonorona, which are encountered outside the forest. These varieties are more easily accessible for local population than the two others which mostly occur inside Vohibe forest. Besides, the use of plants from the forest is regulated by community rules called dina. For example, plants used for house construction, beehives, medicine, ferment for local alcohol drink, or dead trees for fuel can be taken from the part of the forest which is intended for traditional uses. However, those used for house construction, beehives and ferment always need authorization from the president of the local communitybased regulation committee (locally called Vondron'Olona Ifotony or VOI) who regulates the use of forest products. If the trees are used for personal purpose, duty should be paid in advance in order to get the authorization, which can last for 3 months. If needed, it can be renewed after this period. Furthermore, it is noted that plants taken from the forest cannot be sold, but for personal use only. Thus, leaves, petioles and trunk of Bemavo and Horonorona are the parts sold in the market. Table 3 represents the variation of the price of the plant parts used to build houses and the expected longevity of the materials. An example of a house with $12 \mathrm{~m}^{2}$ floor area was taken.

In this table, the price and the longevity depend on the type of materials needed and the variety of Ravenala used. Horonorona lasts for roofs while Bemavo for floor and wall. Materials need to be periodically renewed, 


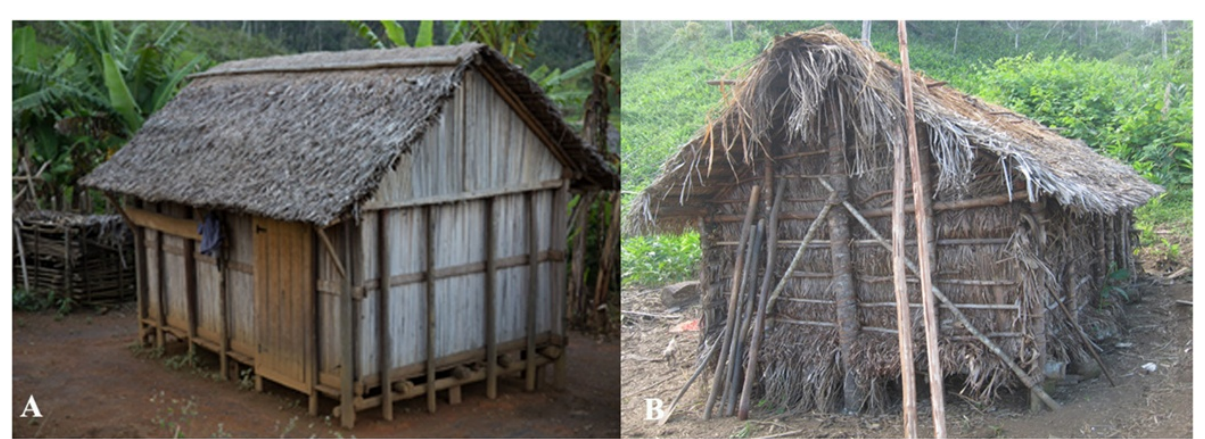

Figure 6 Housing structures built with R. madagascariensis. (A) Traditional house structure seen in Ambalabe using petioles for wall. (B) Temporary house structure built in the crop field with leaves used for roofs and wall.

usually at least every 3 years. Even though local populations are aware of the material's short life span, they still use Ravenala because culturally it is the primary materials used for house building in the Betsimisaraka tribe. It is then a way to identify and preserve this culture. In addition, local population do not know how to manufacture bricks (personal communications), yet the plant is still abundant and easily accessible. Besides, it is an easy material to work with, allowing for fast house construction, which is particularly meaningful in Eastern Madagascar where cyclone damages are quite frequent [23]. In addition, Ravenala is a renewable material, and is inexpensive. Local populations also can directly take for them the materials they need without buying from others.

On the other hand, Ravenala provides a source of income which can improve or stabilize some people's life. The raw materials (leaves, petioles, and trunk) can be sold directly to people in need who cannot go to collect the materials, and handicrafts made from Ravenala, such as winnowing trays or baskets, can be sold in local markets.

While Ravenala madagascariensis is very important for local population in Ambalabe community, not only in terms of uses (first material for house building) but also due to its affordable economic value, it is currently very difficult to find mature trees due to slash and burn cultivation, which is still widely practiced in this area $[24,25]$. Although the number of planted trees is abundant, it takes 15 to 20 years of growth to have a mature trunk for construction. Thus, people resort to the use of younger trees, from which the materials do not last for a long time, which means that the use of Ravenala might become more frequent, and the price might be increased. To tackle the issue, some management practices have been adopted by the local population. For example, they avoid logging Ravenala trees with trunks more than 1 meter in height when practicing the slash and burn cultivation, and field rotation was adopted for crops.

\section{Conclusions}

Ravenala madagascariensis remains an important component in the life of local population in the Ambalabe Rural Commune, especially for house building. There are four varieties of Ravenala madagascariensis found in the study area and all of them are used. Ravenala is used primarily for construction, but other uses have also been noticed including food, medicine and tools. Using Ravenala for house building reduces the pressure on some forest trees, which contributes to the conservation of natural forests and slow growing hardwoods. However, mature trees are needed to source construction materials, and these have become increasingly scarce. While the local population has developed some practices to increase the numbers of large trees, strategies for long term management and sustainable harvests need to be developed.

Table 3 Estimated prices and longevity of plant materials used to build a house of $4 \times 3 \mathrm{~m}$

\begin{tabular}{|c|c|c|c|c|c|}
\hline Parts used & Local name & Part of house & Number needed & Total price & Longevity \\
\hline \multirow[t]{2}{*}{ Leaves } & Bemavo & Roofs & 5-6 bundles of 100 & $\$ 4-5$ & 3 years \\
\hline & Horonorona & & & $\$ 8-10$ & 3-5 years \\
\hline Petioles & Both & Wall & $4-5$ bundles of 100 & $\$ 3-10$ & $5-10$ years \\
\hline \multirow[t]{2}{*}{ Trunks } & Bemavo & Floor & 8 pieces & $\$ 13$ & 6 years \\
\hline & Horonorona & & 12 pieces & $\$ 15$ & 5 years \\
\hline Fibers & Both & Mooring of roof or walls & & $\sim \$ 1$ & 5 years \\
\hline
\end{tabular}




\section{Additional file}

\section{Additional file 1: Fiche d'enquête ethnobotanique.}

\section{Competing interests}

The authors declare that they have no competing interests.

\section{Authors' contributions}

All authors participated in the study design and drafted the manuscript. NR, AR, FR and LR carried out the study and analyzed the data. All authors read and approved the final manuscript.

\section{Acknowledgements}

This research was made possible with the financial support from the William L. Brown Center, Missouri Botanical Garden, in collaboration with the University of Antananarivo. We wish to express our thanks to them, to the staff of Ambalabe project, and to the Ambalabe community and the local population who contributed in this research. We also thank the local guides for their time and sharing their knowledge. We gratefully acknowledge courtesies extended by the Government of Madagascar (Direction Générale des Forêts) and by the Association Nationale pour la Gestion des Aires Protégées, as well as the local authorities in Ambalabe Rural Commune.

\section{Author details}

${ }^{1}$ Missouri Botanical Garden, Madagascar Research and Conservation Program, BP 3391, Antananarivo 101, Madagascar. ²Department of Plant Biology and Ecology, University of Antananarivo, BP 906, Antananarivo 101, Madagascar. ${ }^{3}$ William L. Brown Center, Missouri Botanical Garden, P.O. Box 299, St. Louis, MO 63166-0299, USA.

Received: 26 February 2014 Accepted: 30 June 2014 Published: 15 July 2014

\section{References}

1. Chauvin A, Dewaële A, Ringler D: Madagascar: la forêt d'AmbodirianaManompana, un modèle unique mais menacé de la forêt pluviale humide de la côte Est malgache. Le Courrier de la Nature 2009, 246:28-35.

2. Callmander MW, Phillipson PB, Schatz GE, Andriambololonera S, Rabarimanarivo M, Rakotonirina N, Raharimampionona J, Chatelain C, Gautier L, Lowry PP II: The endemic and non-endemic vascular flora of Madagascar updated. In Proceedings of the XIX ${ }^{\text {th }}$ AETFAT Congress: 26-30 April 2010; Madagascar, Volume 50. Edited by Beau N, Dessein S, Robbrecht E. Meise: National Botanic Garden of Belgium, Scripta Botanica Belgica; 2013:317-321

3. Kress WJ, Schatz GE, Andrianifahanana M, Morland HS: Pollination of Ravenala madagascariensis (Strelitziaceae) by lemurs in Madagascar: evidence for an archaic coevolutionary system? Am J Bot 1994, 81(5):542-551.

4. Hladik CM, Blanc $P$, Hladik A: L'arbre du voyageur. Deuxième partie: reproduction, usages et diffusion horticole. Hommes Plantes 2002, 40:39-47.

5. Blanc P, Hladik A, Rabenandrianina N, Robert JS, Hladik CM: Strelitziaceae: The variants of Ravenala in natural and anthropogenic habitats. In The Natural History of Madagascar. Edited by Goodman SM, Benstead J. Chicago and London: The University of Chicago Press; 2003:472-476.

6. Blanc P, Rabenandrianina N, Hladik A, Hladik CM: Les formes sympatriques et allopatriques du genre Ravenala dans les forêts et les milieux ouverts de l'Est de Madagascar. Revue d'Ecologie (Terre et Vie) 1999, 54:201-224.

7. Hladik A, Blanc P, Dumetz N, Jeannoda V, Rabenendrianina N, Hladik CM: Données sur la répartition géographique du genre Ravenala et sur son rôle dans la dynamique forestière à Madagascar. In Diversité et Endémisme à Madagascar. Edited by Lourenço WR, Goodman S. Paris: Mémoires de la Société de Biogéographie; 2000:93-104.

8. Razanamparany JL, Razafindraoelina RHA, Hladik A, Hladik CM: Peut-on manger le cœur du Ravenala? Aspects écologiques et nutritionnels. Revue d'Ecologie (Terre et Vie) 2005, 60:279-282

9. Nambena J: Analyse de la subsistance paysanne dans un système de production en crise et identification participative de stratégies durables d'adaptation - Cas de Beforona, versant oriental de Madagascar. PhD Thesis. Heidelberg: Ruprecht-Karls-Universität; 2004.

10. Cornet A: Essai cartographique bioclimatique à Madagascar, carte à 1/2 000 000 et notice explicative $N^{\circ}$ 55. Paris: ORSTOM; 1974
11. Martin GJ: Ethnobotany: A Methods Manual. London: Chapman and Hall; 1995.

12. Alexiades MN, Sheldon JW: Selected Guidelines for Ethnobotanical Research: A Field Manual. Bronx, N.Y., U.S.A: New York Botanical Garden; 1996.

13. Cunningham AB: Applied ethnobotany. People, Wild Plant Use and Conservation. London and Sterling: WWF, UNESCO, Royal Botanical Gardens, Kew: Earthscan Publications; 2001.

14. Reyes-García V: Indigenous people, ethnobotanical knowledge, and market economy. A case study of the Tsimane' Amerindians in lowland Bolivia. PhD Thesis. Gainesville: University of Florida; 2001.

15. Cámara-Leret R, Paniagua-Zambrana N, Macía MJ: A standard protocol for gathering palm ethnobotanical data and socioeconomic variables across the Tropics. In Medicinal plants and the legacy of Richard E. Schultes. Proceedings of the Botany 2011 Richard E Schultes Symposium. Edited by Ponman B, Bussmann RW. Trujillo: Graficart; 2012:41-71.

16. Borgatti SP: AnthroPac methods guide. Analytic Technologies: Columbia, SC; 1992.

17. Winch PJ, Wagman JA, Malouin RA, Mehl GL: Recherche qualitative pour des programmes de santé améliorés: Guide aux manuels traitant de la recherche participative en matière de santé de l'enfant, de nutrition et de santé reproductive. USAID, Division du Développement Durable: Afrique; 2001.

18. Quinlan M: Considerations for collecting freelists in the field: examples from ethnobotany. Field Methods 2005, 17(3):1-16.

19. Borgatti SP, Halgin DS: Elicitation techniques for cultural domain analysis. In Ethnographer's Toolkit. Edited by Schensul J, LeCompte M. Walnut Creek: Altamira Press; 1999

20. Priyadarsini SS, Vadivu R, Jayshree N: In vitro and In vivo antidiabetic activity of the leaves of Ravenala madagascariensis Sonn., on alloxan induced diabetic rats. J Pharm Sci Technol 2010, 2(9):312-317.

21. Collins S, Martins X, Mitchell A, Teshome A, Arnason JT: Quantitative ethnobotany of two East Timorese cultures. Economic Botany 2006, 60(4):347-361.

22. Lehman AD: Assessing ethnobotanical knowledge and resources to develop sustainable management plan for the Lokaro reserve in Southeast, Madagascar. PhD Thesis. University of Montana: College of Forestry and Conservation; 2009.

23. Office National pour l'Environnement (ONE): Tableau de bord environnemental - Région Atsinanana. Madagascar: Antananarivo; 2009.

24. Aubert S, Razafiarison S, Bertrand A: Déforestation et systèmes agraires a Madagascar : Les dynamiques des tavy sur la côte orientale. CIRAD: Montpellier; 2003.

25. Ramamonjisoa L, Andrianarivo C, Rabevohitra R, Rakotaniaina N, Rakotovao Z, Rakouth B, Ramamonjisoa BS, Rapanarivo S, Ratsimiala Ramonta I: Situation des ressources génétiques forestières de Madagascar. Note thématique sur les ressources génétiques forestières. Rome: Document de travail FGR/54F. Service de la mise en valeur des ressources forestières, Division des ressources forestières, FAO; 2003

\section{doi:10.1186/1746-4269-10-57}

Cite this article as: Rakotoarivelo et al: Ethnobotanical and economic value of Ravenala madagascariensis Sonn. in Eastern Madagascar. Journal of Ethnobiology and Ethnomedicine 2014 10:57.

\section{Submit your next manuscript to BioMed Central and take full advantage of:}

- Convenient online submission

- Thorough peer review

- No space constraints or color figure charges

- Immediate publication on acceptance

- Inclusion in PubMed, CAS, Scopus and Google Scholar

- Research which is freely available for redistribution 